\title{
文化创新教育融入小学音乐教学的途径研究
}

\author{
王艺霖 \\ 六盘水市钟山区第二实验小学 \\ D O I:10.32629/jief.v2i1.488
}

[摘 要] 随着社会的不断进步, 对于小学教育已经不仅仅只是知识的积累, 更要开拓学生的思维能力, 促进小学生全面发展。音乐教学可以 培养学生的创造力、陶冶情操, 在音乐教育中融入文化创新能够提高教学效果。鉴于此, 本文阐述音乐教学中融入文化创新的重要意义, 探 讨音乐教育中融入文化创新的方法。

[关键词] 文化创新; 小学音乐教学; 研究

新课标课改的持续推进, 我国教育体制也不断改革, 采取更丰富的 教学模式和方法, 提高学生的能力。音乐作为一门艺术学科, 融入文化创 新教育对于学生思维能力的培养有深刻意义。把音乐的魅力作为桥梁, 连 接文化教育, 灵活改变教学内容, 选择适合的教育模式, 使学生不仅陶冶 了情操, 心灵上还得到了完美的净化。优秀的音乐作品无论从歌词上还是 旋律上都可以感染人们, 还能培养学生的爱国思想, 增强民族认同感, 形 成高尚的品德。

\section{1 音乐教学中融入文化创新的意义}

小学音乐教材歌曲有着优美的旋律, 动人的歌词, 还有各种各样的 演唱形式。这些都能打动学生的心。在音乐教学的时候, 要提升他们演唱 的技巧, 更要让他们唱出自己的感情, 让感情很好的融入到整首歌里面, 从唱歌到认识人生、到体会人生。教师在上课过程中应让学生了解歌曲的 背景, 通过唱歌来表达一种怎样的情感在里面, 培养学生热爱祖国、热爱 生活的情感 ${ }^{[1]}$ 。例如: 在教抗日歌曲《保卫黄河》时, 先要告诉学生在怎 样的环境下和心情下创作出这首歌, 然后让学生了解歌词, 深入的体会每 个字在歌词中的含义。像 “风在吼, 马在叫, 黄河在咆哮, 黄河在咆哮 “这 句歌词, 就应该富有怎么的情感在里面。在教学这首歌时, 歌曲可以采用 齐唱、轮唱的演唱形式。具有群众性, 是抗日军民广为传播的一首歌曲。 学习这首歌, 加深了学生对爱国主义的理解。文化教育在小学音乐教育中 的融合, 可以让学生体会更丰富的情感, 了解我国文化发展及文化背景, 为学生树立正确三观打下坚实的基础。

\section{2 音乐教学中融入文化创新过程中存在的问题}

2.1 创新能力不足

在传统音乐教学中, 大多数都以老师单方面进行讲解为主, 教学方 法非常单一, 内容枯燥乏味, 很多老师只为了完成既定教学目标, 不能根 据学生的实际需求和学习兴趣进行教学, 长此以往, 造成学生学习兴趣不 足, 会导致学生的创新能力无法得到培养。

2.2 传统观念束缚比较严重

我国目前很多小学音乐老师都是师范学校毕业, 在教学方法上受传 统观念影响比较大, 除此之外很多学校只关注学生的学习成绩, 对艺术学 科重视度不够, 这种现象严重限制了学生的全面发展。甚至有些学校并没 有把音乐教学归入到学生考核评价系统中, 很多学校的音乐教学体系也不 够完善, 学校并不重视音乐教学的重要性, 使得文化创新很难在小学音乐 中得到发展。

3 音乐教育中融入文化创新的方法

3.1 合理引用文化创新, 丰富教学内容

如今, 随着社会经济的不断发展, 人们生活水平不断提高, 但随之 而来的浪费、环境污染等问题也逐渐凸显, 小学生作为教育的基础阶段, 老师在教学过程中要引导学生形成良好的行为习惯, 对学生进行思想教 育, 培养学生懂得珍惜、感恩。例如: 在学习《弹起我心爱的土琵琶》时, 学生可以先观看《铁道游击队》这部电影, 知道这部作品的背景, 通过视 频可以让学生感受到战争的残酷, 人们饱受煎鰲, 生活在一个怎样水深火
热的年代。接下来学习这首歌时感受到人民为了国家做出的壮举, 深刻的 体会在当时的环境下作品展现出了怎样的一种情怀, 促使我们热爱这来之 不易的生活, 更加珍惜这美好的时光。老师在播放《七子之歌》时, 可以 对歌词进行深入解剖, 唤醒学生对祖国的漛恋之情, 激发学生的民族责任 感。让学生知道祖国与我们在一起, 当鲜艳的五星红旗在澳门上空飘扬时, 爱国之情由然升起。

3.2 备课过程拓展教材内容, 融入文化创新

作为一名人类的工程师, 教师的文化创新意识非常重要。在课堂上 教师通过教材传播知识, 有效合理的备课是关键, 钻研教材分析出每节课 给学生传递德育的重点部分 ${ }^{[2]}$ 。有些教材很明显的传递出要表达的思想, 这是显性教材, 例如: 《爱的奉献》、《没有共产党就没有新中国》、《北京 的金山上》等。也有一些隐性教材, 如: 《听妈妈讲过去的事情》、《南泥 湾》、《说句心里话》等。这些都是得通过教师在备课时挖掘出更深刻的含 义传达给学生的。老师在备课时, 要将课堂所要讲的内容与文化创新相融 合, 要充分了解歌曲背景以及表现出来的思想, 争取让学生在有限的课时 内, 学到更丰富的知识。

3.3 教学过程中进行情感转化

在音乐教学过程中会出现这样的情况: 教师在通过一首表达爱国思想情 节的歌曲时, 学生无法将感情融入到歌曲中。只是对音乐本身简单的一种认 知, 就像在听故事或上一堂有趣的政治课, 只是通过音乐表达出来。因此, 老师可以融入文化创新, 将情感进行转化, 让学生能够感同身受。例如: 在 欣赏《月光下的风尾竹》时, 可以让学生自行发挥, 进行舞蹈表演, 或者让 学生讲述对隐约的感受。老师也可以使用多媒体教学, 播放优美画面, 给学 生带来更直观的视觉享受, 让学生能够领悟到歌曲所表达的情感。 ${ }^{[3]}$

\section{4 结束语}

总而言之, 要运用学生可以理解的方法进行教育才能达到预期效果, 音乐是情感传递的纽带, 是一门艺术, 能形象刻画出人的思想情感。音乐 用强烈感染力, 熏陶着学生。通过积累沉淀, 产生强大的力量。文化创新 与音乐教育的巧妙结合可以更好地培养学生思维能力, 丰富学生的情感, 陶冶情操。音乐能通过声音的传播, 生动的旋律感染着学生们的心灵, 让 他们的感情得到抒发, 潜移默化的影响学生身心发展。

\section{[参考文献]}

[1]项燕萍.创新教学,畅想未来一一探究小学音乐教学中的创新教育 [J].好家长,2017(57):226-226.

[2] 赵利. 创新教育在体校数学教学中的运用探讨 [ J]. 科技 风,2020(06):95.

[3]王琳. 小学音乐教学中创新教育的探索 [J]. 新课程 (小 学),2015(1):130-131.

作者简介: 王艺霖（1984）, 汉族，陕西扶风人，本科，一级教 师 (小), 长期从事将传统文化融入小学音乐教学中的研究, 将文化 创新与音乐教育的巧妙结合达到潜移默化的影响学生身心发展的效 果。 